2021, Volume 16, ATEE 2020 - Winter Conference. Teacher Education for Promoting WellBeing in School. Suceava, 2020, pages: 101-120|

\section{Student-teachers' Experiences During Practicum in Pre- service Teacher Education in Myanmar}

\section{Ei Phyu CHAW 1 Erika KOPP2}

${ }^{1}$ Ph.D. candidate, Faculty of Education and Psychology, Doctoral School of Education, Eotvos Lorand University, Budapest, Hungary, eiphyuchaw05@gmail.com chaw.ei.phyu@ppk.elte.hu

2 Associate Professor, Faculty of Education and Psychology, Doctoral School of Education, Eotvos Lorand University, Budapest, Hungary, kopp.erika@ppk.elte.hu
Abstract: Teacher education program differs internationally in accordance with the admission, assessment, teaching practice period, induction program, professional learning, initial teacher learning, continuous professional development, and performance appraisal systems for recognizing accredited teaching. Experts in teacher education recommends that the practicum is the focus and an integral part of initial teacher education program. In most countries, teacher education programs face difficulties in finding the proper role and form of practice. Referring to National Education Strategic Plan (2016-21) of Myanmar, practicum in teacher preparation program is dull and it has limited guidance and supervision. Moreover, very few publications are available in Myanmar that label the perceptions of teacher candidate on their practicum experience. This study explores student-teachers' experience during practicum in their pre-service teacher education program. The doctoral research will focus on the role of practicum in pre-service teacher education in Myanmar. This document describes the results of the pilot study conducted in 2019, July. The researcher employed convergent mixedmethod design to collect data for the pilot study. Data collection methods include semi-structured focus group interviews and questionnaires. The final year student-teachers $(N=23)$ who were enrolled in 2014 academic year at the Yangon University of Education are the subject of the study. The questionnaire consists of 27 closed items. Fourteen final-year student-teachers discussed their practicum experiences in two focus group interviews. Student-teachers' responses to the questionnaire are mostly positive. In the focus group interview, they mentioned their critical point of views such as their university program could prepare them to some extent for their practicum. There were some differences in responses to the questionnaire and focus group interviews. From the results of the quantitative and qualitative part, the researcher could learn some potential problem areas that can affect the whole doctoral research.

Keywords: student-teacher, practicum, pre-service teacher education

How to cite: Chaw, E. P., \& Kopp, E. (2021). Studentteachers' Experiences During Practicum in Pre-service Teacher Education in Myanmar. In O. Clipa (vol. ed.), Lumen Proceedings: Vol. 16. ATEE 2020 - Winter Conference. Teacher Education for Promoting Well-Being in School. Suceava, 2020 (pp. 101-120). Iasi, Romania: LUMEN Publishing House. https://doi.org/10.18662/lumproc/atee2020/08 


\section{Introduction}

The dimensions of teacher professional knowledge include subject matter knowledge, subject-related teaching knowledge, and general teaching knowledge (Guerriero, 2017). However, Al-Jaro et al. (2017) researched teacher knowledge and highlighted that teachers could develop their pedagogical knowledge through individual practice in teaching. According to Zeichner (1986), the practicum is crucial for prospective teachers to gain new knowledge, skills, and experience. However, there have been problems related to transferring knowledge and skills from teacher preparation for school classrooms. Although there have been different practicum or teaching practice systems in different countries, the common goal is to master student teachers' specific competencies in their university teacher education program. Studies found that practicum provides student-teachers with an interactive experience in schools and prepares student teachers within a framework of theory and practice (Swennen \& Klink, 2009). The research of Edwards et al. (2001) evolves that schools play the prominent role in student-teachers' learning and creating opportunities for improving teaching practice in the classroom.

\subsection{The Context of the Research}

Myanmar is, also known as Burma, the country in Southeast Asia region with around 54 million. Myanmar had been a British colony and gained its independence in 1948. Military rule lasted for over 50 years, and as a result, it weakened the education system in Myanmar. With the development of democracy in Myanmar, Myanmar launched an educational reform in 2011. However, successful reform takes time to achieve and needs to address many challenges. noted that the qualifications of teachers, competency, professional development, student-teacher ratio, the curriculum, learning materials, and infrastructure directly or indirectly affect the quality of education. Improving the quality of education requires focusing on teachers' and teacher educators' quality, competency, professional development, adequacy of teaching -learning materials and infrastructure (Haydena \& Martin, 2013). 
Under Ministry of Education, Universities of Education and Education Colleges run teacher education program. The University of Education in Myanmar offers five years (ten semesters) undergraduate teaching training programs for student-teachers. Under the guidance of the Department of curriculum and methodology, teacher educators from other departments such as Educational Theory and Management, Educational Psychology and Academic departments, student-teachers, school leaders, and teachers from school placement took part in the practicum. Studentteachers have to participate in the practicum as their program requirement. The practicum time is at the end of the fourth semester and sixth semester. The practicum aims to offer a period when student-teachers test what they have learned in Educational Studies and their other subjects through practice. Before the school placement or practicum, student-teachers need to conduct lesson study and peer group teaching, participate in school visits and classroom observation, and prepare lesson plans (Practicum TB Sem 1). The University of Education planned the practicum structure with the help of K-12 schools. Typically, University of Education especially Curriculum and Methodology department organize student-teacher groups into different school for working together during practicum. The University of Education sends an official letter to school leaders in different schools where studentteachers practice their teaching.

\subsection{The Research Gap}

Several studies (Choy et al., 2014; Cortés, 2016; Qazi et al., 2012) have described the significant part of the practicum for student-teachers to bridge the field of theory and practice in pre-service teacher education. However, the practicum period in the pre-service teacher education program of Myanmar is short, and it has not yet developed practice support systems. In Myanmar, the University of Education and Education colleges provide the teacher education program. Practicum or school placement is one part of or module in pre-service teacher education. There is still minimal supervision, feedback, or guidance during practicum (The Government of the Republic of the Union of Myanmar Ministry of Education, 2016). 
Mentoring and induction programs for student-teachers and novice teachers are under-developing in the teacher education program in Myanmar.

During practicum or school placement or practice teaching in actual schools, the cooperative teachers evaluate student-teachers based on their performance. Very few research studies have investigated student-teachers' practicum in teacher preparation program to highlight how the practicum system is processing in Myanmar. Research findings are necessary to underpin ongoing education policy reforms (Darling-Hammond, 2007; Kopp, 2019; Zeichner 2010). One focus of education reforms in Myanmar is the renewal of the practical system of teacher education. Thus, this study is part of doctoral research and explores student-teachers' experiences during their practicum to support a better practice system.

\subsection{Review of related literature}

\section{What is the Practicum?}

"Practicum experiences provide a real-life introduction to the teaching profession, laying the foundation for student-teachers to take on increased teaching responsibilities as student-teachers assist other teachers in their classrooms during their school placements in Basic Education Schools" (Practicum TB Sem 1). Throughout the practicum, student-teachers are expected to test their practice against 'assessment for learning' criteria and keep a daily practicum journal of their teaching experience, ideas they have developed, and how they have affected their students' learning (Practicum TB Sem 1).

\section{Pre-service Teacher Learning during Practicum}

Pre-service teachers gained experience from participation in the activities of the classroom while they are practicing teaching in practice schools. Pre-service teachers have extended their knowledge of teaching in practicum about students, working environment, and school culture (Koşar $\&$ Bedir, 2019). The practicum serves as an ideal context for reflection processes (Cubero-Pérez et al., 2019) and the best chance to show prospective teachers in the classroom. Nkambule and Mukeredzi (2017) 
noted that practicum enhanced student teachers' contextual experiences and knowledge about the teaching profession.

\section{Professional Development through Practicum}

According to Shulman (1986), pedagogical content knowledge referred to "knowledge that integrates the content knowledge of a specific subject and the pedagogical knowledge for teaching of that subject". Referring to Guerriero (2017), pedagogical content knowledge also comprises knowledge of strategies to understand learners. However, teachers can experience pedagogical content knowledge from actual teaching in a classroom and get much knowledge about diverse students when working with the student directly. Arslan \& Ilin (2018) state that practicum in pre-service teacher education enacts a significant role in the professional development of student teachers.

Many authors (Gilliland et al., 2020) argued that the practicum is a complex program. However, it offers various opportunities to prospective teachers useful for their personal and professional improvement within a specific context. It leads pre-service teachers to realize certain teacher qualities necessary for the profession.

\section{Challenges, Fear, and Concern of Student-teachers during their Practicum}

Murray-Harvey et al. (2000) researched stressful sources for student teachers' professional development during practicum and described those stress might affect pupils' performance and anxiety levels. In the study conducted by Kokkinos \& et al. (2016), pupils' disruptive behavior, studentteacher relationship, the supervising teacher, and over workload made student-teachers stressed.

Veenman (1984) analyzed pre-service teachers' problem areas during practicum including classroom management, discipline, student motivation, individual differences, assessing students' work, relationships with parents, inadequate resources. Another study noted that pre-service teachers' problem areas comprise less lesson preparation time, complexities, dynamics, and idiosyncrasies of becoming teachers. 
Many researchers (Ali et al. 2013; Barton et al. 2015; Keser Ozmantar, 2019) found that concerns of student-teachers were attending to relief teaching, lack of resources, fears of academic insufficiency, pedagogical insufficiency, student-related fears, behavior management, and classroom management. Being placed in a separate room from regular teachers and struggling to become real teachers when dealing with unruly students are found as emotional obstacles that can affect pre-service teachers' teaching and learning (Teng, 2017). However, Arslan \& Ilin (2018) commented that the experiences of student-teachers during practicum direct to changes their concerns about teaching. Danner (2014) suggested that it is better to have intervention programs for student-teachers' teaching practice-related anxieties about improving teacher preparation program.

\section{The Importance of Mentor and University Supervisors in Practicum}

School teachers (mentors) guide and support student teachers' learning and professional development in their practicum period. Agudo (2016) presented that mentoring student teachers in their practicum include discussing and negotiating ideas between mentor teachers and student teachers and giving professional advice to improve the teaching practice of student teachers. Pre-service teachers pointed out the importance of collaborating with mentor teachers and they could learn from observing a cooperating teacher in class (Mostofo, 2018; Selçuk \& Yöntem, 2019).

Referring to Li (2016), student-teachers may be more assured of getting help from their supervisors. Many published studies (Dias-Lacy \& Guirguis, 2017; Smith \& Lev-Ari, 2005) describe the importance of mentors in providing professional and personal experiences to pre-service teachers. Lucero \& Roncancio-Castellanos (2019) researched mentoring between preservice and in-service teachers not only comforted new teachers. However, they assisted them in solving the problems and releasing the stress in their first-year professional life. The study of Sulistiyo et al., (2017) recommended that supervising schoolteachers and teacher educators to support studentteachers during the practicum is the most crucial consideration for improving the practicum component. Interestingly, there is no formal mentoring system in teacher preparation program in Myanmar. 


\section{The theoretical framework of the study}

This current study of student teachers' practicum experience is considered under the framework of the experience-based learning theory of Dewey (1963). He distinguished between first and second experience. The first experience comprises real-life experience that includes the interaction between teacher-student, teacher-teacher, and teacher-school environment. The second experience is a reflective experience on that prior experience and includes the things that make the environment and reflection.

To better understand the experience of student-teachers in their early teaching period, it is beneficial to consider the "teacher socialization framework" by Volk (1997). According to Volk (1997), teacher socialization means student-teachers' adaptation to attitudes, opinions, values, and culture of a particular school, group of teachers, students, and school administration. During the practicum period, student-teachers interact with students and experienced teachers and adapt to that school's culture.

\section{Research questions/Aims of the research}

The study seeks to examine experience of student-teachers during their practicum in their pre-service teacher education program in Myanmar.

This study addresses the questions of:

1. What are the perceptions of student-teachers on their activities during teaching practice period in school?

a) What are the critical areas of student-teachers' success during their practicum?

2. How do student-teachers see university program for their teaching preparation for the practicum?

3. How do student-teachers solve the problems they encounter during their practicum?

\section{Research methods}

In this study, a mixed-method research is conducted, using both quantitative and qualitative approaches. Parallel or convergent mixedmethod design is applied where quantitative and qualitative phases occur in a 
parallel manner, and these two phases considers an equal attempt for the same basic research questions (Teddlie \& Tashakkori, 2009).

\subsection{Sampling}

For the quantitative (questionnaire) study, a purposive sampling method was used for choosing participants. The criteria for choosing participants are those student-teachers who had practicum experiences during their teacher education program. The snowball sampling method was employed for the qualitative (interview) study. Snowball sampling is a popular purposive sampling method involving participants to identify other participants for the study (Teddlie \& Tashakkori, 2009).

\subsection{Participants}

The study participants were final year student-teachers from the preservice teacher education program in the one University of Education in Myanmar. Participants were enrolled in the 2014 academic year as first-year student-teachers, and they are in their final year of the 2019 academic year when they took part for this study. Twenty-three participants completed answering the questionnaire. The age range of the participants was 20-23. Nine of the participants were male, while the remaining fourteen were female. Two groups of fourteen participants (seven in each group) discussed their experiences during practicum for semi-structured focus group interviews.

\subsection{Materials and Instruments}

\section{(1) Questionnaire}

For the quantitative study, the questionnaire was employed for exploring student-teachers' experiences during practicum. The questionnaire included 27 items and comprised 5-point Likert Scale items, from strongly agreed (SA) to (SD) strongly disagree. The questionnaire was adopted from the student-teacher survey questionnaire by Allen \& Wright (2013). From their questionnaires, the categories and items related to the theoretical framework and research questions of the present study are selected and modified according to Myanmar teacher education conditions. The 
questionnaire has two key components. The first part includes the demographic data of participants, and the second part comprises 27 items for exploring the experience of student-teachers.

(2) Focus group interview

For the qualitative study, semi-structured interview questions were evoked based on the research questions and theoretical framework. Semistructured interviews include inquiry questions that provoke participants' further amplification, explanations, and interpretation (Yin, 2009). The researcher conducted two focus group interviews with the participants to discuss their practicum experiences. The focus group interview can draw out different responses within groups, arouse additional contributions, and enclose a more fantastic range of perspectives and experiences (Yin, 2009). Participants in focus group interviews are in their final year University program and had known each other for almost four years. The researcher conducted two focus group interviews to get detailed responses from each participant from each group and to save the time.

\subsection{Procedure}

For the quantitative study, the questionnaire was distributed to student-teachers with the consent form. After two weeks, the questionnaire was collected from each of the 23 participants. The return rate was $100 \%$. Then, data was input into SPSS software by defining the value for the variables. SPSS version 25 was used to analyze statistical data. Descriptive statistics were calculated. Based on the frequency of the response on each item, the percentages of strongly agree (SA) and agree (A) were combined; and did the same way for strongly disagree (SD) and disagree (D). The percent distribution based on student-teachers' responses are reported in Table 1 (see in the Results section).

For the qualitative study, consent forms were distributed and got their agreement before conducting the interview. Participation is voluntary. Semi-structured focus group interviews were conducted to get in-depth information about participants' perceptions and experiences during their practicum. The focus group interview was audio-recorded, and some points 
were noted. At the beginning of the interview, the researcher asked participants general questions concerning their practicum experience. It lasted for approximately 90 minutes. Participants were then requested to describe specific experiences during their practicum.

To interpret focused group interviews, the researcher used the guidance of qualitative focus group analysis of Miles \& Huberman (1994), King (1998), and Blair (2015). Based on these analytical techniques, first, the interview recording was translated. Second, the translation of the recording was transferred into sentences. Then, the central theme of the interview questions was pulled out. Following literature notes are noted, focused group interview responses were coded and matched two key codes and created the theme.

\section{Results}

\subsection{Quantitative Results}

Table 1. The percentage distribution of student-teachers' perceptions of their

\begin{tabular}{|c|c|c|c|}
\hline \multirow{2}{*}{ Items } & \multicolumn{2}{|c|}{ Responses } & \multirow[b]{2}{*}{$\mathrm{U}$} \\
\hline & $\mathrm{SA} / \mathrm{A}$ & $\mathrm{SD} / \mathrm{D}$ & \\
\hline $\begin{array}{l}\text { 1. gave a moment to merge theory and practice related to } \\
\text { teaching. }\end{array}$ & $95.6 \%$ & - & $4.3 \%$ \\
\hline 2. educate about the idea of teaching. & $91.3 \%$ & $4.3 \%$ & $4.3 \%$ \\
\hline 3. relate the activities during practicum to university lesson & $60.9 \%$ & $30.4 \%$ & $8.7 \%$ \\
\hline $\begin{array}{l}\text { 4. based more on actual classroom experience, less on } \\
\text { theory. }\end{array}$ & $52.1 \%$ & $34.8 \%$ & $13 \%$ \\
\hline $\begin{array}{l}\text { 5. learned more during practicum than at university } \\
\text { program }\end{array}$ & $91.3 \%$ & - & $8.7 \%$ \\
\hline 6. fulfill presumption in connecting theory and practice. & $95.6 \%$ & - & $4.3 \%$ \\
\hline 7. University lesson has become more meaningful & $69.6 \%$ & $8.7 \%$ & $21.7 \%$ \\
\hline 8. student misbehavior interferes with teaching. & $91.3 \%$ & $4.3 \%$ & $4.3 \%$ \\
\hline 9. burden of non-academic, clerical work. & $86.9 \%$ & $4.3 \%$ & $8.7 \%$ \\
\hline 10. decided to teach as a profession & $100 \%$ & - & - \\
\hline 11. motivate in teaching. & $95.7 \%$ & - & $4.3 \%$ \\
\hline 12. improve professional skills. & $95.7 \%$ & - & $4.3 \%$ \\
\hline 13. experience problems and prospects & $95.6 \%$ & - & $4.3 \%$ \\
\hline 14. broaden content knowledge & $100 \%$ & & \\
\hline 15. teach how to plan, prepare, and present lesson & $100 \%$ & & \\
\hline 16. use reinforcement and assessment skills & $91.3 \%$ & & $8.7 \%$ \\
\hline
\end{tabular}




\begin{tabular}{|c|c|c|c|}
\hline 17. Some schools did not like student-teachers. & $30.4 \%$ & $43.5 \%$ & $26.1 \%$ \\
\hline 18. teachers in that school are not friendly & $69.5 \%$ & - & $8.7 \%$ \\
\hline 19. lack of instructional materials & $65.2 \%$ & $17.4 \%$ & $17.4 \%$ \\
\hline 20. given more lessons & $47.8 \%$ & $21.7 \%$ & $30.4 \%$ \\
\hline 21. misbehaving students and less management over them. & $26 \%$ & $60.8 \%$ & $13 \%$ \\
\hline 22. students do not respect & $13 \%$ & $65.2 \%$ & $21.7 \%$ \\
\hline 23. are not fully involved in school activities. & $30.4 \%$ & $52.1 \%$ & $17.4 \%$ \\
\hline $\begin{array}{l}\text { 24. overloaded by assigned duties of the cooperating } \\
\text { teachers }\end{array}$ & $39.1 \%$ & $34.7 \%$ & $26.1 \%$ \\
\hline 25. University teachers played an important role & $73.9 \%$ & $4.3 \%$ & $21.7 \%$ \\
\hline 26. colleague teacher/s played an important role & $95.6 \%$ & $4.3 \%$ & - \\
\hline $\begin{array}{l}\text { 27. The school administration's behavior is supportive and } \\
\text { encouraging. }\end{array}$ & $78.3 \%$ & $13 \%$ & $8.7 \%$ \\
\hline
\end{tabular}

The percentage of student teachers' responses from table 1 was discussed. Nearly all the participants $(95.6 \%)$ believe that practicum experience gave them the moment to merge theory and practice (see statement 1). Besides, all student-teachers (100\%) also strongly agreed that practicum broadens their subject knowledge and preparing lessons and strengthens their decision for the teaching profession (see statements 10, 14, and 15). Most respondents (95.7\%) assumed that teaching practice helped them master their professional skills (see statement 12). In statement 26, student teachers responded that their colleague teachers played an essential role in connecting theory and practice (95.6\%). Student-teachers (95.7\%) also agreed with the fact that teaching practice helped them to develop their interest in teaching (see statement 11), and $91.3 \%$ of them admitted practicum experience teaches them more than at university programs (see statement 5).

The percentage (precisely 68\%) of student-teachers argued about misbehaving students, and they had poor management on them (see statement 21). Interestingly, student-teachers do not agree with statement 22 that highlights school students do not respect them $(65.2 \%)$. Studentteachers claimed they were not fully involved in all school activities $(52.1 \%$, statement 23) as they actively participated in school activities. Based on the responses provided by student-teachers toward the questionnaire, it can be said that student-teachers' perceptions of their practicum experience are affirmative. 


\subsection{Qualitative results}

The central theme from focus group coding was summarized into four themes: activities during the practicum, successful stories, perceptions of the university program, and problem-solving strategies.

\section{Theme 1: Activities during practicum}

Student-teachers recounted their participation in different activities in their respective schools during practicum periods, such as co-curricular activities, school donation ceremonies, helping in administrative work and leading debate, essay writing competition in schools, and correction of student answer books. Some responses are highlighted:

"During my first practicum period, I taught students co-curriculum subjects such as physical exercise, music, dancing, and the art of housework." (Student-teacher 1)

"I took part in the school donation ceremony as the practicum period is set during these days. On that ceremony day, school leaders, teachers, and students donate money and useful things to the monastery." (Student-teacher 2)

\section{Theme 2: Successful stories}

Student-teachers told their successful stories enthusiastically and proudly. Some had a success story related to teaching methods, while other student-teachers can manage the student's behavioral problems. One student-teacher said that he had success in reconciling conflicts between teachers. Another student-teacher described how she had motivated her students to read many books and get general knowledge.

"I faced behavioral problems at the beginning of teaching, but I could manage, and I was successful after two weeks teaching period." (Student-teacher 5)

"When I made corrections in the students' books, I checked their mistakes carefully and corrected them, and I wrote remarks for each student. After practicum teaching, I received good feedback from the students for checking their books carefully so they could see their mistakes." (Studentteacher 8) 


\section{Theme 3: University preparation}

Student-teachers discussed university preparation for their practicum, in that the lessons learned in university programs are valuable and essential to some extent for their teaching practicum. One student-teacher admitted that her thinking skill has improved because of knowledge in the university program (Student-teacher 2). Student-teachers suggested that the university preparation curriculum in university programs needs to be updated and should include activities.

"I am satisfied with Educational subjects from the university program, but I need more practical knowledge about how to teach science and art lessons." (Student-teacher 13)

"I think there is a gap between theory given in university lecture and when we practice teaching in a real classroom.” (Student-teacher 8)

"We think the curriculum in university programs needs to be updated and less focused on the lecture." (Student-teacher 9 and 14)

\section{Theme 4: Problem-solving strategies}

Student-teachers expressed they got help from experienced teachers if they had problems with teaching.

"I asked my senior teachers and used manual teacher books with guided answers if I had teaching-related problems."(Student-teacher 4)

They can solve student misbehavior problems with the help of the school leader. Sometimes, student-teachers discussed their problems with their peers from other schools. Student-teachers got some valuable suggestions from their parents, and they can solve some of their teachingrelated problems by themselves.

"I got suggestions from my aunt as she is an experienced teacher to solve behavioral problems (e.g., talking while I am teaching) of students." (Student-teacher 6)

\section{Discussions}

According to the findings of the quantitative investigation, studentteachers' responses to their practicum experiences are mostly positive. Tuli and File (2009) and Allen and Wright (2014) emphasized that the practicum is the unique approach for student-teachers to apply the educational theories 
in real classroom. From quantitative results, it can be concluded that participants valued their experience during their practicum and met their expectations for the school placement. These responses are like the study results of (Cairney \& Breen, 2017). Teacher candidates experienced a significant change in themselves, and their learning occurred through socialization with students, teachers, and school culture in an undergraduate practicum course.

Most of the responses from the questionnaire are the same as the interview results, in that their challenges are more concerned with teaching and not with behavioral problems. Among them, student-teachers strongly agreed that their senior teachers played a significant role in integrating theory and practice. These results align with previous research in Agudo (2016), respondents are satisfied with their mentor feedback and meeting their needs. Student-teachers admitted they got support from university teachers, colleague teachers, and school administrators. Though there is no formal mentoring and induction in teacher preparation program (see the context of the study), those colleague teachers and school administrators in Myanmar are informally supporting student-teachers during practicum.

Student-teachers add a more critical point in semi-structured focus group discussions. They were not satisfied with their university program preparation. They needed more practicum time, more practical lessons about teaching in the curriculum than lectures. They thought there was a difference between theory learned in university programs and school classrooms. These findings are congruent with Cortés (2016) study, arguing that it is required to provide the chance for student-teachers to put what they learned in the university training program into actual teaching situations.

\section{Conclusions}

To explore student-teachers' experience in their practicum in their pre-service teacher education in Myanmar, the researcher used a parallel mixed-method design. Both quantitative and qualitative findings reveal the overview of perceptions of student-teachers' experience about their practicum and detailed information about their opinions in four themes. As for research question 1, student-teachers have a wonderful experience in 
their practicum time as they took part in school activities. Student-teachers had successful stories, such as effective teaching, managing classrooms, and student misbehavior problems. As for research question 2, student-teachers respond (in a focus group interview) concerning university programs that they could not use their knowledge from their university program in a real classroom. Not all the lessons taught in a university program are not practical teaching practices. In answering research question 3, studentteachers solved the problems concerning teaching with the help of experienced teachers and sometimes themselves. Their school leaders and their peers also support them to solve the behavioral problems of students.

Some differences are found in reaction to the questionnaire and focus group interviews. The participants' answers to the questionnaire are constructive. It seems that participants are not frank to express their opposing views in the written version. They might think that the questionnaire is testing them as an examination paper. The critical point of view in the focused group discussion that they did not describe in the questionnaire is mentioned. However, this study highlights the points that can be elaborated in the whole doctoral study and gives some new ideas to improve the practicum structure in teacher preparation program.

\section{References}

Agudo, M., J. (2016). What Type of feedback do Student-teachers expect from their School Mentors during Practicum Experience? The Case of Spanish EFL Student-teachers. Australian Journal of Teacher Education, 41(5), 36-51. http://ro.ecu.edu.au/ajte/vol41/iss5/3

Ali, M. S., Othman, A. J., \& Karim, A. F. A. (2013). Issues and Concerns Faced by Undergraduate Language Student-teachers during Teaching Practicum Experiences. The Malaysian Online Journal of Educational Science, 2(3), 22-30. https://files.eric.ed.gov/fulltext/EJ1086203.pdf

Al-Jaro, M., Asmawi, A., \& Hasim, Z. (2017). Content Analysis of the Pedagogical Content Knowledge in the Curriculum of Yemeni EFL Teacher Education Programme. Arab World English Journal, 8(1), 264-279.

https://doi.org/10.24093/awej/vol8no1.19 
Allen, J. M., \& Wright, S. E. (2014). Integrating theory and practice in the preservice teacher education practicum. Teachers and Teaching, 20(2), 136-151. https://doi.org/10.1080/13540602.2013.848568

Arslan, Y. F., \& Ilin, G. (2018). The Effects of Teaching Practicum on EFL PreService Teachers' Concerns. Journal of Language and Linguistic Studies, 14 (2), 265-282. https://files.eric.ed.gov/fulltext/EJ1184382.pdf

Barton, G. M., Hartwig, K. A., \& Cain, M. (2015). International students' experience of practicum in teacher education: An exploration through internationalization and professional socialization. Australian Journal of Teacher Education, 40(8), 149-163. http://dx.doi.org/10.14221/ajte.2015v40n8.9

Blair, E. (2015). A reflexive exploration of two qualitative data coding techniques. Journal of Methods and Measurement in the Social Sciences, 6(1), 14-29. https://doi.org/10.2458/v6i1.18772

Cairney, K., \& Breen, A. V. (2017). Listening to https://doi.org/10.2458/v6i1.18772 their Lives: Learning through Narrative in an Undergraduate Practicum Course. The Canadian Journal for the Scholarship of Teaching and Learning, 8(3). http://ir.lib.uwo.ca/cjsotl rcacea/vol8/iss $3 / 3$

Choy, D., Wong, A. F. L., Goh, K. C., \& Ling Low, E. (2014). Practicum experience: Pre-service teachers' self-perception of their professional growth. Innovations in Education and Teaching International, 51 (5), 472-482. https://doi.org/10.1080/14703297.2013.791552

Cortés, Y. A. (2016). Unveiling Pre-Service Teachers' Attitudes Toward Teaching: The Role of Pedagogical Practicums. PROFILE Issues in Teachers' Professional Development, 18 (2), 47. https://doi.org/10.15446/profile.v18n2.49591

Cubero-Pérez, R., Cubero, M., \& Bascón, M. J. (2019). The Reflective Practicum in the Process of Becoming a Teacher: The Tutor's Discursive Support. Education Sciences, 9(2), 96. https://doi.org/10.3390/educsci9020096

Danner, R. B. (2014). Student Teachers' Perceptions of Sources of Teaching practice-related Anxieties. Journal of Teaching and Teacher Education, 2(1), 4759. http://dx.doi.org/10.12785/itte/020104

Darling-Hammond, L. (2007). Recognizing and enhancing teacher effectiveness: A Policy Maker's Guide. 
https://www.researchgate.net/publication/281996909 Recognizing and enhancing teacher effectiveness

Dewey, J. (1963). Experience and education. Collier Books

Dias-Lacy, S. L., \& Guirguis, R. V. (2017). Challenges for New Teachers and Ways of Coping with Them. Journal of Education and Learning, 6(3), 265. https://doi.org/10.5539/jel.v6n3p265

Edwards, A. (2001). Researching Pedagogy: A Sociocultural Agenda. Pedagogy, Culture \& Society, 9(2), 161-86. https://doi.org/10.1080/14681360100200111

Gilliland, B., Tanaka, J., Schwartz, \& Díez-Ortega, M. (2020). Multiple Dimensions of Teacher Development on an International Practicum. The Electronic Journal for English as a Second Language, 23(4), 225-245.

https:// files.eric.ed.gov/fulltext/EJ1242675.pdf

Guerriero, S. (Ed.). (2017). Pedagogical Knowledge and the Changing Nature of the Teaching Profession. OECD. https://doi.org/10.1787/9789264270695-en

Haydena, M. \& Martin, R. (2013). Recovery of the Education System in Myanmar. Journal of International and Comparative Education, 2(2), 47-57. https://doi.org/10.14425/00.50.28

Keser Ozmantar, Z. (2019). A Phenomenological Study of Practicum Experience: Preservice Teachers' Fears. International Journal of Progressive Education, 15(1), 135-150. https://doi.org/10.29329/ijpe.2019.184.9

King, N. (1998). Template analysis. In G. Symon \& C. Cassell (Eds.), Qualitative methods and analysis in organizational research: A practical guide (pp. 118-134). Sage Publications Ltd.

Kokkinos, C. M., Stavropoulos, G., \& Davazoglou, A. (2016). Development of an instrument measuring student-teachers' perceived stressors about the practicum. Teacher Development, 20(2), 275-293.

https://doi.org/10.1080/13664530.2015.1124139

Kopp, E. (2020). A pedagógusok folyamatos szakmai fejlo"dése és tanulása az oktatási rendszer szintjén [Teachers' continuous professional development and learning at the level of education system]. Neveléstudomány, 1, 62-82. https://nevtud.ppk.elte.hu/dstore/document/3090/nevelestudomany 202 $0 \quad 1 \quad 62-82 . p d f$ 
Koşar, G. \& Bedir, H. (2019). A comprehensive evaluation of practicum experience: From the view of pre-service EFL teachers. International Online Journal of Education and Teaching (JET), 6(4). 1001-1016.

http://iojet.org/index.php/IOJET/article/view/724

Li, L. (2016). Factors of Practicum Experience for Pre-service Teacher's Sense of Readiness for Their Teaching Career [Master of Education Project, University of Victoria]. DSpace

Library.https://dspace.library.uvic.ca/bitstream/handle/1828/7337/Li Lu han_MEd 2016.pdf?isAllowed $=y \&$ sequence $=4$

Lucero, E., \& Roncancio-Castellanos, K. (2019). The pedagogical practicum journey towards becoming an English language teacher. Profile: Issues in Teachers' Professional Development, 21(1), 173-185.

https://doi.org/10.15446/profile. v21n1.71300

Miles, M. B., \& Huberman, M. (1994). Qualitative Data Analysis: A Sourcebook of New Methods (2nd ed). Sage Publications.

Mostofo, J. (2018). Summer practicum partnership: impact on the efficacy of preservice teachers. Journal of Instructional Research, 7, 40-54. https:// files.eric.ed.gov/fulltext/EJ1188319.pdf

Murray-Harvey, R., T. Slee, P., Lawson, M. J., Silins, H., Banfield, G., \& Russell, A. (2000). Under Stress: The concerns and coping strategies of teacher education students. European Journal of Teacher Education, 23(1), 19-35. https://doi.org/10.1080/713667267

Nkambule, T., \& Mukeredzi, T. G. (2017). Pre-service teachers’ professional learning experiences during rural teaching practice in Acornhoek, Mpumalanga Province. South African Journal of Education, 37(3), 1-9. https://doi.org/10.15700/saje.v37n3a1371

Qazi, W., \& Rawat, K. J., Thomas, M. (2012). The Role of Practicum in Enhancing Student Teachers' Teaching Skills. American Journal of Scientific Research, 44, 44-57. https://www.researchgate.net/profile/Martin-Thomas14/publication/324720990 The Role_of Practicum_in_Enhancing_Stude nt 'Teachers' 'Teaching Skills/links/5adefb81458515c60f618756/TheRole-of-Practicum-in-Enhancing-Student-Teachers-Teaching-Skills.pdf Selçuk, M., \& Yöntem, E. G. (2019). Beyond Practicum: Interplay between Prospective EFL Teachers' Conceptualizations of Field Experience and 
Teaching Career. Advances in Language and Literary Studies, 10(1), 154.

https://doi.org/10.7575/aiac.alls.v.10n.1p.154

Shulman, L. S. (1986). Those who understand: Knowledge growth in teaching.

Educational Researcher, 15(2), 4-14.

https://doi.org/10.3102/0013189x015002004

Smith, K., \& Lev-Ari, L. (2005). The place of the practicum in pre-service teacher education: The voice of the students. Asia-Pacific Journal of Teacher Education, 33(3), 289-302. https://doi.org/10.1080/13598660500286333

Sulistiyo, U., Mukminin, A., Abdurrahman, K., \& Haryanto, E. (2017). Learning to

Teach: A Case Study of Student Teachers' Practicum and Policy

Recommendations. The Qualitative Report, 22(3), 712-731.

https://doi.org/10.46743/2160-3715/2017.2671

Swennen, A., \& van der Klink, M. (Eds.). (2009). Becoming a Teacher Educator.

Springer Netherlands. https://doi.org/10.1007/978-1-4020-8874-2

Teddlie, C., \& Tashakkori, A. (2009). Foundations of mixed methods research: Integrating

quantitative and qualitative approaches in the social and behavioral sciences. SAGE.

Teng, (2017). Emotional Development and Construction of Teacher Identity:

Narrative Interactions about the Pre-service Teachers' Practicum

Experiences. Australian Journal of Teacher Education, 42(11), 117-143.

https:// files.eric.ed.gov/fulltext/EJ1161164.pdf

The Government of the Republic of the Union of Myanmar Ministry of Education

(2016). National Education Strategic Plan - NESP (2016-21).

https://www.britishcouncil.org/sites/default/files/myanmar national edu cation strategic plan 2016-21.pdf

Tuli, F., \& File, G. (2010). Practicum Experience in Teacher Education. Ethiopian

Journal of Education and Sciences, 5(1), 107-117.

https://doi.org/10.4314/ejesc.v5i1.56316

Veenman, S. (1984). Perceived Problems of Beginning Teachers. Review of

Educational Research, 54 (2), 143-178.

https://doi.org/10.3102/00346543054002143

Volk, D. (1997). Questions in Lessons: Activity Settings in the Homes and School

of Two Puerto Rican Kindergartners. Anthropology \& Education

Quarterly, 28, 22-49.

Yin, R. K. (2009). Case study research: Design and methods (4th ed.).Sage Publications. 
Zeichner, K. (1986). The practicum as an occasion for learning to teach. The South Pacific Journal of Teacher Education, 14(2), 11-27. https://doi.org/10.1080/0311213860140202

Zeichner, K. (2010). Rethinking the Connections Between Campus Courses and Field Experiences in College- and University-Based Teacher Education. Journal of Teacher Education, 61(1-2), 89-99. https://doi.org/10.1177/0022487109347671 